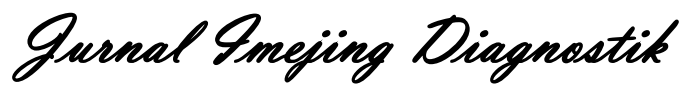

e-ISSN 2621-7457, p-ISSN $\underline{2356-301 X}$ http://ejournal.poltekkessmg.ac.id/ojs/index.php/jimed/index

\title{
Teknik Penyinaran Radioterapi Tiga Dimensi (3D) pada Pasien dengan Kasus Kanker Sarkoma Sinovial di Unit Radioterapi Instalasi Radiologi RSUP dr. Kariadi Semarang
}

\author{
Rizky Dika Hermawan ${ }^{1}$, Siti Masrochah ${ }^{2}$, Fatimah $^{2}$ \\ 1)Dr. Kariadi Hospital, Semarang, Indonesia \\ 2,3) Poltekkes Kemenkes Semarang, Indonesia \\ Corresponding Author: Rizky Dika Hermawan \\ e-mail:Rzkdika@gmail.com
}

Received: January $29^{\text {th }}, 2021$; Revised: January $30^{\text {st }}, 2021$; Accepted: February $31^{\text {st }}, 2021$

\begin{abstract}
Background: Synovial sarcoma is a neoplasm that is clinically, morphologically, and genetically distinct. This spindle cell tumor shows epithelial differentiation that is not constant. Radiotherapy is one of the modes of treatment for synovial sarcoma cancer by using ionizing rays to kill or eliminate (eradicate) all cancer cells in the tissue. The goal of radiotherapy (radiation therapy) is to provide the required number of radiation doses precisely to the radiation target area without damaging the surrounding healthy tissue.

Methods: The type of research used is an observational approach. With the patient object the remaining palmar synovial sarcoma. Data collection was carried out by direct observation of the patient. Data analysis was carried out by collecting data and documents, then drawing conclusions.

Results: 3D irradiation technique in patients with synovial sarcoma cases at Dr. Kariadi Semarang is the administration of patient registration and doctor's examination with a plan of administering a total dose of 40 Gy with fractionation of 2 Gy per day and superficial brachytherapy or 30 gy electron. Making prints and checking the ct scan in the area of the hand then calculating the doctor and calculating tps. Verification of the ap field and then irradiating at an angle of PA $\left(180^{\circ}\right)$, AP $\left(0^{\circ}\right)$

Conclusion: 3D irradiation technique in patients with synovial sarcoma cases at Dr. Kariadi Semarang is patient administration, radiation planning, making molding and ct scan, contouring and tps calculations then doing field leverage and irradiation.
\end{abstract}

Keywords: Sarkoma synoval; Radiotherapy 3D; Cancer.

\section{Pendahuluan}

Sarkoma sinovial adalah salah satu neoplasma yang berbeda secara klinis, morfologis, dan genetik. Tumor sel spindel ini menunjukkan diferensiasi epitel yang tidak konstan, terdiri dari pembentukan kelenjar dan memiliki translokasi kromosom spesifik t $(\mathrm{X} ; 18)$ (p11; q11). Ini mewakili sekitar $5,6 \%$ sampai $10 \%$ dari semua sarkoma jaringan lunak. Sarkoma sinovial pada daerah kepala dan leher pertama kali dijelaskan oleh Jernstrom pada tahun 1954, dan Ambleetal, menunjukkan sekitar 9\% dari tumor ini terjadi di daerah kepala dan leher (Arun Priya, 2017).

Radioterapi menjadi salah satu moda pengobatan kanker sarcoma sinovial yaitu dengan menggunakan sinar pengion untuk membunuh atau menghilangkan (eradikasi) seluruh sel kanker yang ada di jaringan tersebut. Tujuan radioterapi (terapi radiasi) adalah dengan memberikan sejumlah dosis radiasi yang diperlukan secara tepat pada daerah target radiasi tanpa merusak jaringan sehat di sekitarnya.

Oleh karena latar belakang tersebut penulis membuat makalah ini untuk mengatahui bagaimana cara prodesur radioterapi di rumah sakit kariadi semarang.

\section{Metode}

Jenis Penelitian ini adalah dengan pendekatan observasional. Dengan objek seorang pasien dengan kasus Sarkoma synovial palmar sinistra. Pengumpulan data dilakukan dengan observasi langsung terhadap pasien. Analisa data dilakukan dengan pengumpulan data dan dokumen, kemudian penarikan kesimpulan. 
Hasil dan Pembahasan

\section{Paparan Kasus}

Identitas Pasien

$\begin{array}{ll}\text { Nama pasien } & \text { : Ny KY } \\ \text { Umur } & : 42 \text { thn } \\ \text { Alamat } & : \text { Semarang } \\ \text { No. Rekam medis } & \text { : C81xxxx } \\ \text { Diagnosa } & \text { : Sarkoma synovial Palmar } \\ & \text { Sinistra }\end{array}$

Teknik Penyinaran 3D pada pasien dengan kasus Sarkoma synovial di RSUP Dr. Kariadi Semarang

a. Administrasi Pendaftaran Pasien

Pasien mendaftar ke loket pendaftaran terlebih dahulu, selanjutnya data-data pasien dicatat oleh petugas loket meliputi nama pasien, nomor catatan medik, umur, alamat, dokter pengirim serta diagnosa penyakit.

Kemudian pasien menuju bagian informasi untuk mendapatkan penjelasan mengenai jadwal program dan melengkapi syarat-syarat administrasi. Petugas informasi membuat status penyinaran pasien dan melengkapi dengan datadata pasien.

b. Pemeriksaan Dokter

Setelah selesai mendaftar di loket administrasi pasien datang ke Poli Radioterapi untuk melakukan konsultasi dengan Dokter Spesialis Onkologi Radiasi terlebih dahulu dan membawa permintaan dokter pengirim dan hasil pemeriksaan penunjang yang telah dilakukan seperti hasil Patologi-Anatomi, hasil CT Scan, hasil MRI, dan hasil lab. Kemudian Dokter akan memeriksa berkas kelengkapan pasien, melakukan anamnesa, memberikan penjelasan/informasi tentang penyakitnya dan menentukan rencana tindakan radioterapi selanjutnya. Jika pasien telah menerima keputusan dokter tentang rencana tindakan radioterapi yang akan dilakukan, maka pasien diberikan lembar inform consent untuk ditandatangani oleh pasien dan keluarganya.

Perawat memberikan informasi/arahan tambahan seperlunya kepada pasien untuk meneruskan proses pelayanan pasien ke simulator atau pasien diminta datang untuk melanjutkan pemeriksaannya, sesuai jadwal yang telah ditentukan sebelumnya, dengan melengkapi surat-surat, hasil pemeriksaan lainnya yang diperlukan.

Rencana pemberian dosis penyinarannya adalah untuk Sarkoma sinovial diberikan total dosis 40 Gy dengan fraksinasi 2 Gy tiap harinya dan brakhiterapi superfisial atau electron $30 \mathrm{gy}$.

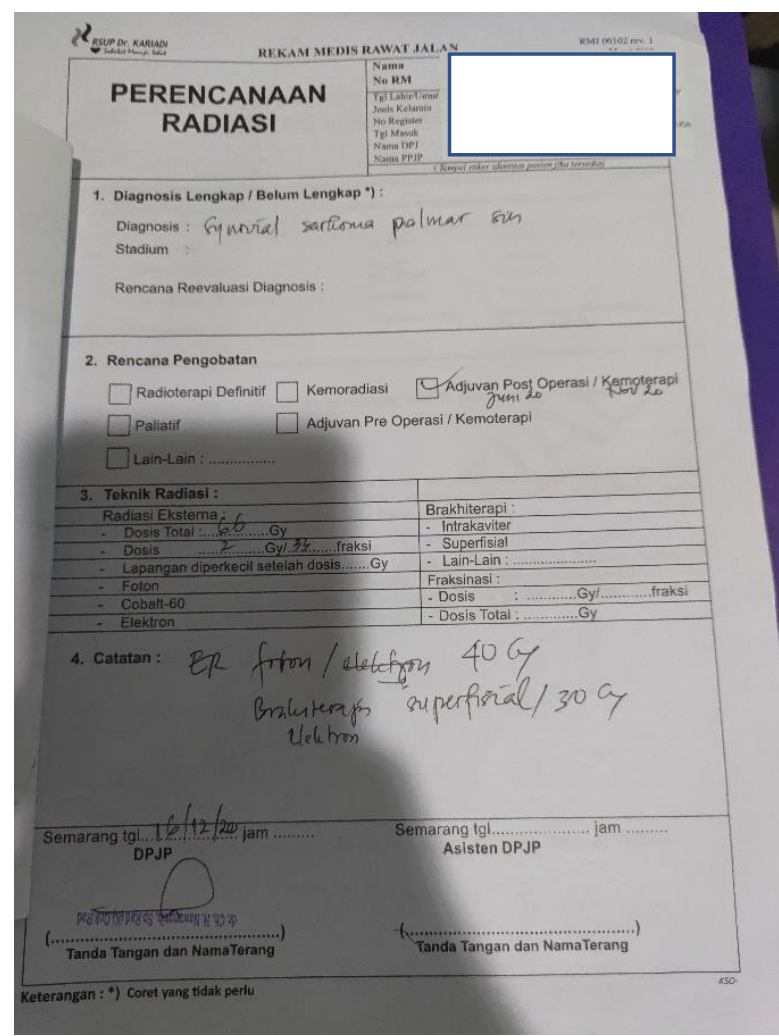

Gambar 1. Lembar perencanaan radiasi

\section{c. Pemeriksaan CT Simulator}

Setelah selesai pemeriksaaan dokter, pasien selanjutnya masuk ke ruang CT Simulator dan dilakukan pemeriksaan dengan alat CT Simulator, merupakan salah satu alat bantu dalam pelayanan radioterapi, yang pada dasarnya adalah proses pencitraan dari CT Scan dimana hasil dari CT Scan tersebut nantinya akan digunakan untuk contouring dan perhitungan di TPS. Hasil CT Simulator diperlukan agar Dokter dapat melihat organ per slice untuk dilakukan contouring, menentukan OAR (Organ At Risk), target volume benarbenar mencapai sasaran secara optimal dan akurat.

1) Persiapan pasien

Pasien datang ke ruang Simulator dengan membawa kelengkapan hasil pemeriksaan laboratorium, hasil CT Scan, PA dan MRI.

2) Persiapan alat dan bahan

Persiapan alat dan bahan yang diperlukan di ruang CT Simulator antara lain : Base Plate kepala,gabus biru, media kontras, cairan infus, spuit, abocath surplug, alkohol swap, injector, spidol hitam, plester.

3) Persiapan CT Simulator 
a) Dilakukan warming up CT Simulator terlebih dahulu

b) Tekan tombol hijau (tombol on) pada panel listrik

c) Tekan tombol power pada CPU

d) Tunggu sampai program siap digunakan

e) Tekan tombol kontrol panel pada Gantry

f) Pastikan semua pintu pada ruang CT Simulator tertutup rapat

g) Klik dailyprep > Klik fast calibration > Klik OK

h) Tunggu gantry berputar selama 1-2 menit

i) Tekan tombol start pada konsul (proses warmup dimulai)

j) Tunggu sampai proses warmup selesai > Klik quit

4) Tatalaksana di ruang CT Simulator

a) Sebelum dilakukan CT Simulator, pasien dibuatkan fiksasi berupa moulding thermoplast terlebih dahulu. Proses pembuatan moulding thermoplast :

(1) Pasien diberikan edukasi tentang prosedur pembuatan moulding tangan dan prosedur CT Simulator secara jelas sampai pasien mengerti tentang prosedur tersebut.

(2) Kemudian pasien diposisikan diatas meja pemeriksaan dengan tangan diletakan diatas kepala dan diatas gabus biru

(3) Thermoplast dilebur menggunakan aquades yang dipanaskan dengan alat selama \pm 7-10 menit (sampai thermoplast berubah menjadi transparan)

(4) Atur posisi tangan pasien lurus sejajar dengan bantuan laser.

(5) Setelah thermoplast siap dan pasien sudah dalam posisi sempurna, angkat thermoplast lalu di bersihkan menggunakan handuk kering agar tidak panas dan basah

(6) Letakkan thermoplast di tangan pasien, kunci thermoplast pada 3 point agar tidak bergeser

(7) Tekan thermoplast sesuai dengan tangan pasien.

(8) Tunggu sampai thermoplast mengering.

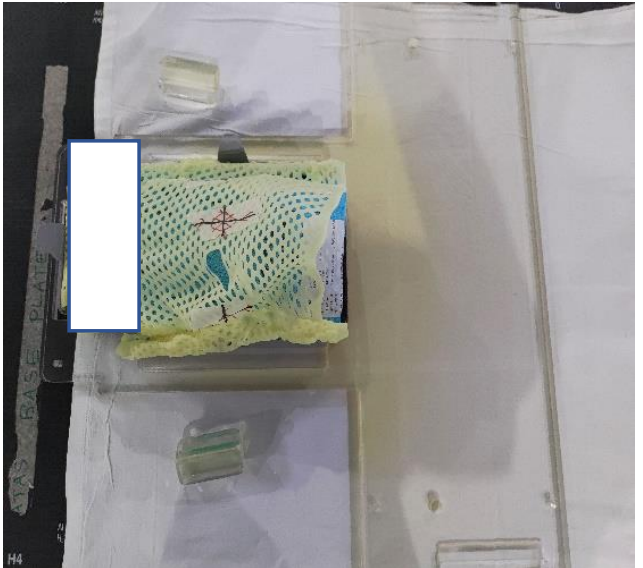

Gambar 2. Moulding tangan

b) Prosedur pemeriksaan CT Simulator

(1) Pasien dipasang infus set terlebih dahulu untuk media kontras saat CT Scan.

(2) Pasien diatur di meja pemeriksaan menggunakan bantal kepala dan moulding thermoplast hingga posisi pasien fix dan dipasang safety belt agar pasien tidak bergerak.

(3) Posisi laser diatur pada tangan pasien.

(4) Kemudian beralih ke meja console, Klik icon "New Patient " untuk entry data pasien, meliputi : patient ID (No. Rekam Medik pasien), patient name (nama pasien), sex (jenis kelamin), birth date (tanggal lahir), age (umur), weight (berat badan), referring physician (dokter pengirim), radiologist (dokter radiolog), operator (radiografer), history (riwayat penyakit/diagnosa), dan exam description (jenis pemeriksaan).

(5) Buat scout (scannogram) "organ" dalam profil AP dan Lateral.

(6) Atur batas atas dan batas bawah irisan axial sesuai dengan indikasi pemeriksaan.

(7) Klik "Confirm " untuk memulai scanning "organ" non kontras.

(8) Klik " next series" untuk melakukan scanning "organ" post kontras dengan pengaturan scan parameter sama dengan scanning "organ" non kontras.

(9) Atur scan delay fase arteri 20s

(10) Klik " preset list " untuk memberi tanda injeksi media kontras. 
(11) Klik " Confirm ", tekan "move to scan", dan tekan "start scan " untuk scanning anatomical reference.

(12) Klik " End Exam " untuk mengakhiri scanning "organ" post kontras.

\section{d. Tata laksana TPS}

Setelah selesai dilakukan CT Simulator status pasien dan hasil CT Simulator dibawa ke ruang TPS untuk dilakukan perhitungan dosis dan waktu penyinaran oleh fisikawan medis. Pada prinsipnya TPS merupakan seperangkat komputer, berisi perangkat lunak software program yang khusus digunakan untuk penghitungan dosis dan waktu penyinaran pasien dan perangkat keras yang terdiri dari CPU, monitor, keyboard, mouse dan printer.

Treatment Planning System adalah suatu rangkaian yang harus dilalui sebelum penyinaran. Fungsi TPS adalah untuk menentukan konfigurasi berkas penyinaran yang meliputi banyak faktor antara lain sudut gantry, kolimator, ukuran dan bentuk lapangan penyinaran serta pembobotan berkas radiasi agar tujuan dari radioterapi sesuai dengan yang diharapkan yaitu memiliki nilai terapeutik rasio yang baik dengan memberikan dosis yang optimal pada organ target dan meminimalisir dosis yang diterima oleh organ at risk disekitar target.

Data dari ruang CT Simulator berupa CD yang berisi hasil CT Simulator pasien. Yang nantinya akan dilakukan contouring terlebih dahulu oleh Dokter untuk mendapatkan target volume, OAR di sekitar tumor, GTV, PTV dan CTV.

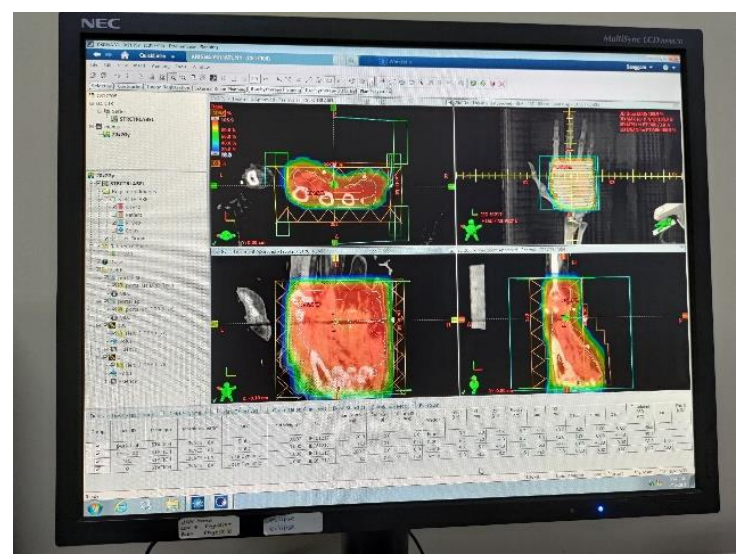

Gambar 3. Hasil Konturing Dokter Onkologi

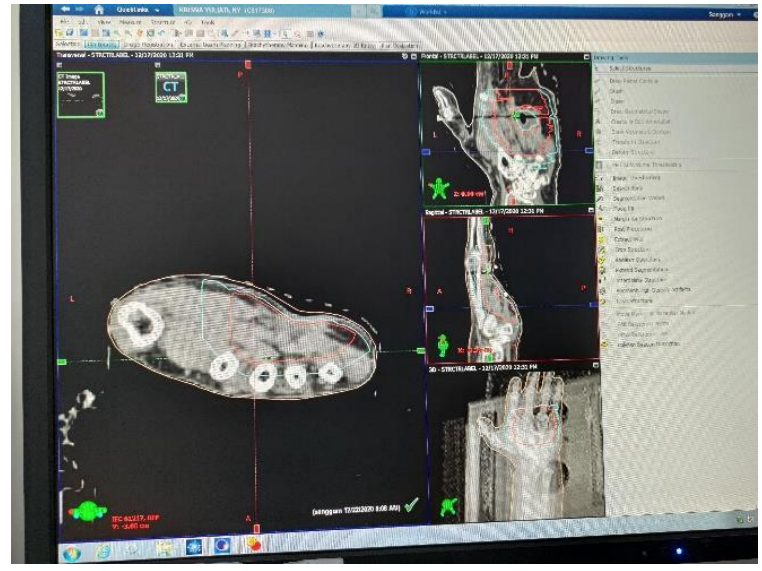

Gambar 4. Hasil Perhitungan TPS

Kemudian hasil contouring tersebut dikirim ke komputer TPS yang selanjutnya akan dihitung oleh Fisikawan. Hasil perhitungan dari TPS meliputi penentuan teknik yang dipakai, persebaran dosis penyinaran, waktu penyinaran, hasil pergeseran meja dari titik origin, titik isocenter, sudut sinar atau sudut gantry, dan sudut perputaran meja.

e. Tatalaksana di ruang penyinaran

Setelah hasil penghitungan waktu penyinaran dari TPS selesai, maka status pasien diserahkan ke pesawat Linac untuk dilakukan penyinaran.

1) Persiapan Pasien

Persiapan pasien selama terapi radiasi eksternal tidak membutuhkan persiapan secara khusus, hanya memperhatikan pada kondisi umum pasien dengan melihat hasil laboratorium Hemoglobin ( $\mathrm{Hb}$ ), Lekosit dan trombosit normal. Sebelum dilakukan penyinaran, pasien dan keluarga pasien diberikan edukasi terlebih dahulu mengenai prosedur penyinaran sampai mengerti akan prosedurnya.

2) Persiapan Pesawat Linac

a) Hidupkan ketiga monitor

b) Putar kunci ke kanan pada box mesin Varian

c) Tekan tombol warna merah pada CPU 4DITC ( untuk 4DITC dan Image View )

d) Masukkan password pada monitor 4DITC

e) Klik 2x pada icon PV Aplication dan icon Treatment

f) Hidupkan monitor CCTV dalam ruangan treatment

g) Lakukan cek: 
(1) Adakah air menggenang di bawah gantry pada posisi $90^{\circ}$

(2) Posisikan gantry dan kolimator pada $0^{0}$

(3) Posisikan meja pemeriksaan di bawah gantry

(4) Buka pintu mesin samping kanan

Cek Water Level : Pada posisi optimal

Cek Water Temperature: Pada angka $40^{\circ}$

Cek Water Pressure : Pada angka 70

Cek Gas Pressure $\quad$ : Pada angka 30

h) Cek active lock pada monitor mesin Varian

i) Kembali ke meja control, hidupkan power on MLC Controller

j) Klik icon T pada monitor 4DITC tunggu sampai informasi data MLC ready for treatment, apabila ada eror pada pesannya ulangi kembali dengan menulis wr (windows restart) -> enter

k) Klik standby

1) Tekan enter pada control console pada pilihan Morning Checkout

m) Tekan enter pada pilihan Calibration \& Check

n) Putar kunci pada control consule -> Tekan Beam On

o) Apabila sudah muncul pesan Treatment Complete $\rightarrow$ Putar kembali kunci control consule ke kiri

p) Tekan F1 ( exit ) kemudian isi parameter Water Level

Water Temperature

Water Pressure

Gas Pressure

q) Save frequency No

r) Print No

s) Tekan yes -> enter

t) Klik exit standby

u) Pilih pada tampilan select treatment $R V$ Mode Up

3) Prosedur penyinaran

Sebelum dilakukan penyinaran, Radiografer melakukan verifikasi data pasien terlebih dahulu. Data pasien harus sesuai antara rencana pemberian dosis oleh Dokter dengan perhitungan dari TPS oleh Fisikawan diantaranya dosis penyinaran, jumlah lapangan penyinaran, dan waktu penyinaran. Kemudian dilakukan verifikasi lapangan penyinaran yang sudah dihitung di TPS dengan lapangan penyinaran yang akan dilakukan. Setelah dilihat dan disetujui oleh Dokter kemudian dilakukan penyinaran radiasi. Verifikasi lapangan penyinaran dilakukan sebelum penyinaran pertama dan saat penyinaran ketiga.

a) Prosedur verifikasi lapangan penyinaran yang dilakukan adalah sebagai berikut :

(1) Radiografer mencatat data pasien pada buku kunjungan.

(2) Radiografer mengisi status pasien (luas lapangan, teknik yang digunakan, dosis, penyinaran ke berapa, waktu penyinaran).

(3) Pasien diposisikan prone diatas meja pemeriksaan dengan tanga direntangkan, menggunakan bantal gabus biru dan moulding thermoplast.

(4) Lampu kolimator dan lampu skala jarak dihidupkan. Kemudian mengatur posisi laser sesuai dengan titik origin yang sudah dibuat di CT Simulator.

(5) Setelah itu melihat pergeseran meja yang sudah direncanakan pada TPS yang meliputi pergeseran vertical, longitudinal dan lateral.

(6) Mengatur posisi meja pemeriksaan sesuai dengan perhitungan TPS, selanjutnya memberikan tanda pada moulding thermoplast yang nantinya berfungsi untuk titik penyinaran selanjutnya.

(7) Membuka Portal untuk dilakukan verifikasi sebelum dilakukan penyinaran.

(8) Kemudian membuka data pasien di komputer kontrol untuk ditampilkan parameter-parameter penyinaran.

(9) Memilih Portal untuk verifikasi lapangan penyinaran biasanya dalam posisi AP dan lateral > Klik mode up.

(10) Beralih ke control panel > Klik enter > isi MU $1>$ Klik enter > putar kunci beam > Klik beam on .

(11) Setelah selesai beam > putar kembali kunci ke posisi off. Kemudian dilanjutkan ke portal posisi lateral.

(12) Setelah selesai, hasil verifikasi 
dilihat oleh Dokter apakah sudah sesuai dengan planning di TPS, apabila belum selesai maka dilakukan pergeseran meja kembali sesuai dengan arahan Dokter. Kemudian dilakukan verifikasi ulang.

(13) Hasil verifikasi di tanda tangani oleh Dokter apabila sudah sesuai dengan planning dari TPS.

(14) Selanjutnya dilakukan penyinaran dengan sudut gantry, sudut meja sesuai dengan planning dari TPS.

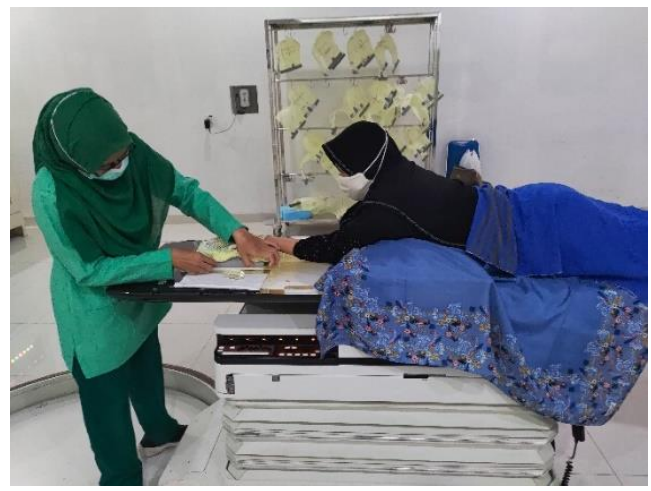

(a)

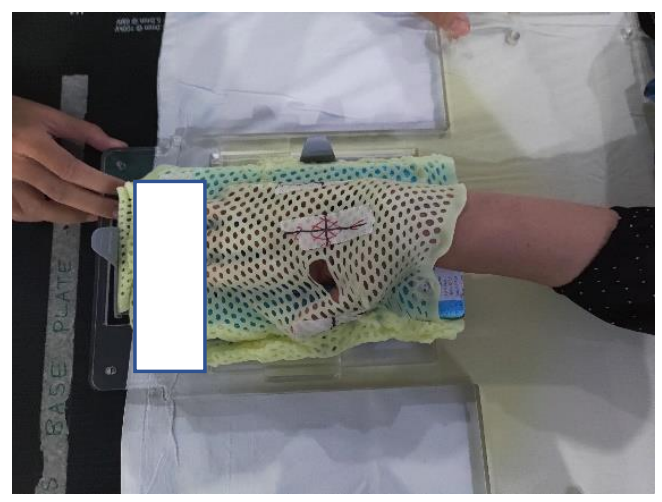

(b)

Gambar 5. (a) Posisi pasien dan (b) Pemasangan Moulding Tangan

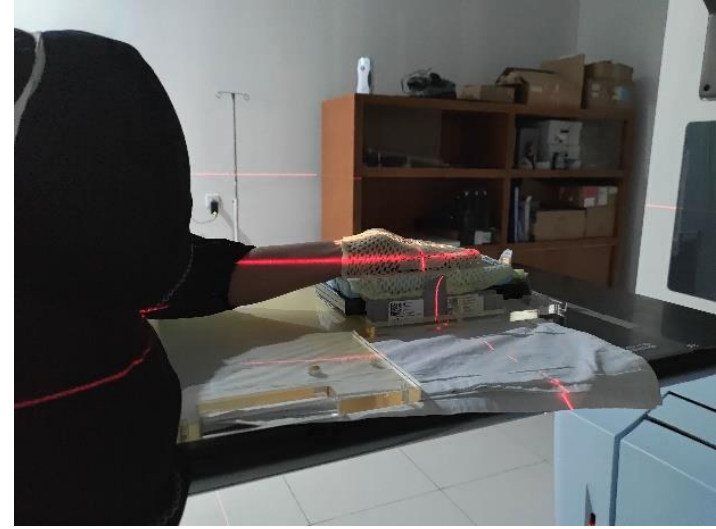

Gambar 6. Verifikasi Lapangan Penyinaran

b) Prosedur penyinaran yang dilakukan adalah sebagai berikut :

(1) Radiografer mencatat data pasien pada buku kunjungan.

(2) Radiografer mengisi status pasien (luas lapangan, teknik yang digunakan, dosis, penyinaran ke berapa, waktu penyinaran).

(3) Pasien diposisikan prone diatas meja pemeriksaan dengan tanga direntangkan, menggunakan bantal gabus biru dan moulding thermoplast.

(4) Lampu kolimator dan lampu skala jarak dihidupkan. Kemudian mengatur posisi laser sesuai dengan titik penyinaran.

(5) Kemudian membuka data pasien di komputer kontrol untuk ditampilkan parameter-parameter penyinaran. Meliputi sudut sinar PA $\left(180^{\circ}\right), \operatorname{AP}\left(0^{\circ}\right)$

(6) Memilih sudut sinar pada data penyinaran > Klik mode up .

(7) Beralih ke control panel > Klik enter > isi MU $1>$ Klik enter > putar kunci beam $>$ Klik beam on .

(8) Setelah selesai beam > putar kembali kunci ke posisi off. Kemudian dilanjutkan ke sudut sinar lainnya. 


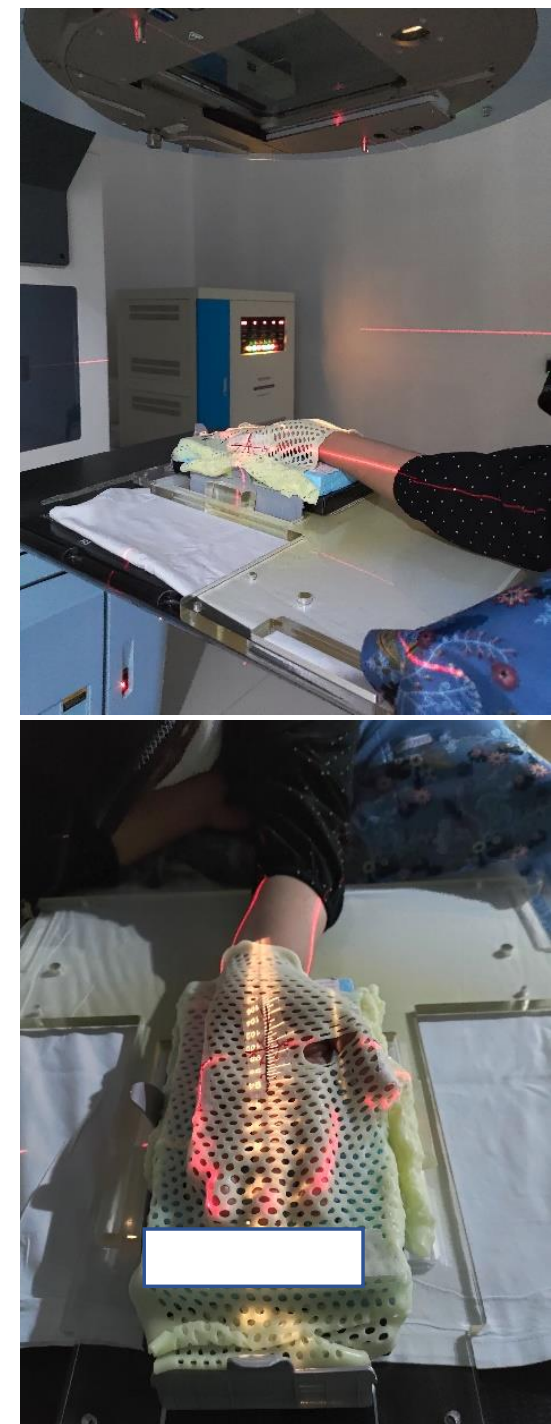

Gambar 7. Penyinaran pada pasien

Selama menjalani terapi radiasi, Dokter memantau kondisi umum pasien dengan melakukan pemeriksaan pasien setiap $5 \mathrm{x}$ penyinaran, mencatat keluhan pasien, memberikan obat, bila perlu dan pemeriksaan darah rutin ( $\mathrm{Hb}$, Lekousit, Trombosit). Setelah pasien selesai penyinaran selama $20 \mathrm{x}$ dilanjutkan dengan booster electron $30 \mathrm{gy}$.

Teknik Penyinaran 3D pada pasien dengan kasus Sarkoma synovial di RSUP Dr. Kariadi Semarang:

1. Administrasi Pendaftaran Pasien

Pasien mendaftar ke loket pendaftaran terlebih dahulu, selanjutnya data-data pasien dicatat oleh petugas loket meliputi nama pasien, nomor catatan medik, umur, alamat, dokter pengirim serta diagnosa penyakit. Kemudian pasien diberi penjelasan mengenai jadwal program dan melengkapi syarat-syarat administrasi.

\section{Rencana Penyinaran}

Sebelum dilakukan penyinaran, pasien membawa permintaan dokter pengirim dan hasil pemeriksaan penunjang yang telah dilakukan seperti hasil Patologi-Anatomi, hasil CT Scan, dan hasil MRI. Kemudian Dokter melakukan anamnesa, memberikan penjelasan/informasi tentang penyakitnya dan menentukan rencana tindakan radioterapi selanjutnya. Setelah itu pasien diberikan lembar inform consent untuk ditandatangani oleh pasien dan keluarganya. Rencana pemberian dosis penyinarannya adalah untuk Sarkoma sinovial diberikan total dosis 40 Gy dengan fraksinasi 2 Gy tiap harinya dan brakhiterapi superfisial atau electron $30 \mathrm{gy}$.

3. Persiapan Pasien

Persiapan pasien selama terapi radiasi eksternal tidak membutuhkan persiapan secara khusus, hanya memperhatikan pada kondisi umum pasien baik dengan melihat hasil laboratorium Hemoglobin ( $\mathrm{Hb})$, Lekosit dan trombosit normal.

4. CT Simulator

Di ruang CT Simulator, pasien dan keluarga pasien diberikan edukasi terlebih dahulu mengenai prosedur pembuatan moulding kepala dan prosedur CT Simulator hingga mengerti kemudian mengisi lembar edukasi pasien dan keluarga pasien. Setelah itu pasien dibuatkan fiksasi moulding thermoplast pada tangan pasien. Kemudian dilakukan CT Simulator dan ditentukan titik origin dari hasil CT Scan tersebut.

5. Treatment Planing System

Di ruang TPS, data pasien dari CT Simulator dilakukan contouring terlebih dahulu oleh Dokter untuk mendapatkan target volume, OAR di sekitar tumor, GTV, PTV dan CTV.

Kemudian hasil contouring tersebut dikirim ke komputer TPS yang selanjutnya akan dihitung oleh Fisikawan. Hasil perhitungan dari TPS meliputi penentuan teknik yang dipakai, persebaran dosis penyinaran, waktu penyinaran, hasil pergeseran meja dari titik origin, titik isocenter, sudut sinar atau sudut gantry, dan membatasi sudut penyinaran dengan pengaturan kolimator MLC dan menggunakan teknik 3D. 
6. Teknik Penyinaran

Sebelum dilakukan penyinaran, radiografer melakukan verifikasi data pasien diantaranya dosis penyinaran, jumlah lapangan penyinaran, dan waktu penyinaran. Kemudian dilakukan verifikasi lapangan penyinaran yang sudah dihitung di TPS. Verifikasi lapangan penyinaran dilakukan sebelum penyinaran pertama dan saat penyinaran ketiga. Setelah dilihat dan disetujui oleh Dokter kemudian dilakukan penyinaran radiasi.

Penyinaran dilakukan sesuai dengan perhitungan dari TPS meliputi sudut sinar yang terdiri dari lapangan penyinaran pada dengan sudut PA $180^{\circ}$ dan sudut AP $0^{\circ}$,

\section{Simpulan}

Teknik Penyinaran 3D pada pasien dengan kasus Sarkoma synovial di RSUP Dr. Kariadi Semarang meliputi pendaftaran pasien di loket pendaftaran, rencana pemberian dosis oleh Dokter, diberikan total dosis 40 Gy dengan fraksinasi 2 Gy tiap. Pemeriksaan CT Simulator, pasien menggunakan masker thermoplast dan dengan penentuan titik origin pada daerah tangan. Pelaksanaan contouring oleh Dokter pada target volume, OAR di sekitar tumor, GTV, PTV dan CTV. Treatment Planning System (TPS) menggunakan teknik 3D. Verifikasi lapangan penyinaran dilakukan 2 lapangan AP dan Lateral. Penyinaran Radioterapi dilakukan sesuai dengan perhitungan dari TPS meliputi lapangan penyinaran pada sudut PA $180^{\circ}$ dan sudut AP $0^{\circ}$.

\section{Daftar pustaka}

Arun Priya S.1, Saravanan Vasudevan2, Anu Priya S.3, Aishwarya S. (2017). Synovial SarcomaA Review. www.ijcmr.com

Beyzadeoglu, M, 2010, Basic Radiation Oncology, Springer Heidelberg Dordrecht, London

Susworo, 2017, Dasar-dasar Radioterapi dan Tata Laksana Radioterapi Penyakit Kanker, Universitas Indonesia, Jakarta

https://www.docdoc.com/medicalinformation/conditions/synovialsarcoma?lang=id. Diakes pada tanggal 2 Maret 2021 